\title{
Kehidupan Sosial-Ekonomi Masyarakat di Jawa 1830-1870
}

\author{
Wafiyatu Maslahah* \\ Arif Wahyu Hidayat*
}

\begin{abstract}
Abstrak
Kegagalan sistem sewa tanah yang dilakukan pada pemerintahan Inggris, menjadikan pelajaran bagi pemerintah Belanda yang telah kembali menduduki Hindia-Belanda. Situasi keuangan Belanda pada saat itu sangat terpuruk sehingga Johanes van den Bosch sebagai Gubernur Jendral yang baru mendapatkan tugas untuk meningkatkan produk tanaman ekspor, meskipun pada saat pemerintahan Belanda sebelumnya sudah menerapkan hal tersebut. Gagasan pemecahan untuk mengatasi keterpurukan keuangan yang dicetuskan oleh van den Bosch walaupun sama dengan pemerintahan yang lama tetapi terdapat perbedaan yakni pengenalan sistem tanam paksa, yang kemudian terkenal dengan nama Cultuurstelsel. Aturan mengenai pelaksanaan sistem tanam paksa pada dasarnya masih dapat diterima karena masih berada dalam koridorkoridor kewajaran yang masuk akal. Permasalahannya ialah dalam praktiknya sistem tanam paksa menyimpang dari aturan yang ditetapkan. Hal ini berakibat penderitaan rakyat yang dikarenakan sebagian tanah milik petani harus ditanami tanaman ekspor yang kurun waktunya sama dengan waktu masa tanam padi. Pelaksanaan sistem tanam paksa telah mempengaruhi dua unsur pokok kehidupan agraris pedesaan Jawa, yaitu tanah dan tenaga kerja. Selain itu, tanam paksa juga mempengaruhi kehidupan sosial-ekonomi masyarakat di Jawa 18301870.
\end{abstract}

Kata Kunci : tanam paksa, kehidupan sosial masyarakat

\section{Pendahuluan}

Indonesia pernah dijajah Inggris selama lima tahun antara 1811-1816. Gubernur Jendral Raffles merupakan salah seorang tokoh yang mengenalkan sistem sewa tanah di Jawa. Hal ini didasarkan atas pengakuan kedaulatan Inggris oleh raja sehingga tanah menjadi milik negara. Teori ini yang menjadi dasar dalam penerapan sistem sewa tanah di Jawa. Gagasan ini muncul dari pengalaman Inggris di India.

Ketika Raffles meninggalkan Jawa pada tahun 1816, maka hak atas penguasaan wilayah tersebut dikembalikan
Inggris kepada Belanda. Belanda meninjau kembali kebijaksanaan mereka atas Jawa. Gubernur Jenderal Van Der Cappellen menerapkan suatu kebijaksanaan, bahwa penduduk Jawa bebas menggunakan tanah mereka untuk menanam yang mereka kehendaki, tapi sebagai imbalan atas hak ini, orang-orang tersebut harus membayar sewa atas tanah. Pada tahun 1827, sebagian besar sewa harus dibayarkan baik dalam bentuk mata uang perak atau emas, dan sisanya dalam bentuk mata uang tembaga. Diharapkan dengan konsep liberal ini, penduduk Jawa kemudian akan

* Wafiyatu Maslahah adalah Dosen Program Studi Pendidikan Ilmu Sosial Fakultas Psikologi dan Ilmu Pendidikan Universitas Islam Raden Rahmat Malang

* Arif Wahyu Hidayat adalah Dosen Program Studi Pendidikan Sejarah dan Sosiologi FPISH IKIP Budi Utomo Malang 
memproduksi hasil bumi yang lebih dapat di pasarkan, dan dengan demikian mampu membayar sewa tanah.

Kegagalan sistem sewa tanah dalam merangsang para petani pedesaan untuk meningkatkan produksi tanaman ekspor yang dilakukan selama pemerintahan komisaris Jendral Van der Cappelen dan Du Bus de Gisignies, telah memberikan alasan bagi penggantinya untuk menetapkan kebijakan baru yang dianggap lebih mampu menjawab tuntutan yang mendesak. Johanes van den Bosch yang diangkat menjadi Gubernur Jendral di Indonesia pada tahun 1830 mendapatkan tugas untuk meningkatkan produksi tanaman ekspor yang tidak dapat dicapai pada pemerintahan sebelumnya.

Tugas ini sangat mendesak, karena keadaan keuangan Negeri Belanda yang sangat parah. Negeri Belanda pada waktu itu memiliki beban hutang yang sangat besar yang tidak dapat ditanggulangi sendiri sehingga mencari solusi di daerah jajahannya yaitu Indonesia. Gagasan pemecahan yang dicetuskan oleh van den Bosch adalah pengenalan sisten tanam paksa, yang kemudian terkenal dengan nama Cultuurstelsel (Kartodirjo dan Suryo, 1991: 53).

Sistem tanam paksa yang diterapkan sejak tahun 1830 ini, pada dasarnya adalah suatu penghidupan kembali sistem eksploitasi dari masa VOC yang berupa penyerahan wajib. Raffles pernah menghapus sistem penyerahan wajib dan menggantinya dengan system pajak tanah (land rent), dalam rangka usaha untuk mendorong petani meningkatan produksi tanaman ekspor. Usaha Raffles gagal karena kebijaksanaannya tidak mampu menciptakan hubungan yang efektif antara pemerintah dengan para petani yang tidak lagi menggunakan penghubung para bupati dan kepala-kepala desa.

Sistem tanam paksa pada dasarnya merupakan penyatuan antara sistem penyerahan wajib dengan sistem pajak tanah. Maka dari itu, ciri pokok sistem tanam paksa terletak pada keharusan rakyat untuk membayar pajak dalam bentuk barang, yaitu berupa hasil tanaman pertanian mereka, dan bukan dalam bentuk uang seperti yang berlaku dalam sistem pajak. Menurut pemikiran van den Bosch, bahwa dengan pungutan pajak dalam bentuk barang (natura), maka produksi tanaman perdagangan akan dapat dikumpulkan dalam jumlah yang besar.

Produksi tanaman ekspor yang berhasil dikumpulkan itu, diharapkan akan dapat dikirimkan ke negeri induk yang kemudian dipasarkan di pasaran dunia secara luas baik di Eropa maupun Amerika. Pemasaran produksi tanaman ekspor di dunia itu akan mendatangkan keuntungan besar baik kepada pemerintah maupun para pengusaha di Negeri Belanda, sehingga hutang negeri induk segera dibayar. Meskipun culturestelsel tidak mengadakan 
jenis tanaman baru dan cara pengoperasian yang masih sama dengan cara di zaman VOC, yaitu menguasai tanah tenaga kerja dan hasil tanamannya untuk diekspor namun culturestelsel telah menciptakan suatu tahap baru dalam eksploitasi sosial eknomi dan transformasi terhadap pedesaan Jawa. Johanes van den Bosch adalah konseptor sekaligus pelaksana politik tanam paksa yang diangkat sebagai Gubernur Jendral di Indonesia, dia beranggapan pemerintah Hindia Belanda merasa dirinya sebagai pengganti raja-raja yang berhak melakukan tindakan seperti yang dilakukan raja (Husken, 1998: 75-76).

Berdasarkan ketentuan-ketentuan tanam paksa, sebenarnya hal tersebut tidak begitu merugikan bangsa Indonesia, namun penyimpangan dalam pelaksanaan politik itu telah membawa kesengsaraan bagi rakyat pribumi. Terlepas dari permasalahan tersebut pelaksanaan tanam paksa tentunya mengalami dampak terhadap kehidupan sosial masyarakat di Jawa. Fenomena kehidupan sosial masyarakat di Jawa 18301870 akan dibahas lebih lanjut.

\section{PEMBAHASAN}

Golongan konservatif yang menguasai pemerintahan kolonial pada masa awal abad XIX memandang politik eksploitasi dengan penyerahan paksa peninggalan VOC sangat cocok untuk mengelola Hindia Belanda sebagai daerah wingewest atau daerah yang menguntungkan negara induk. Sistem penyerahan paksa itu dapat diterapkan dalam usaha eksploitasi produksi pertanian tanah jajahan yang langsung ditangani oleh pemerintah kolonial.

Eksploitasi produksi pertanian yang dilakukan oleh pemerintah kolonial ini diwujudkan dalam bentuk perkebunan negara. Sejak itulah Hindia Belanda memasuki masa sistem tanam wajib atau tanam paksa (cultuurstelsel). Sistem tanam paksa dilaksanakan melalui alat birokrasi pemerintah yang berfungsi sebagai pelaksana langsung dalam proses mobilisasi sumber perekonomian berupa tanah dan tenaga kerja.Sistem tanam paksa lebih mengutamakan peningkatan hasil produksi tanaman ekspor yang sangat laku di pasaran Eropa, untuk itu pemerintah kolonial memperkenalkan tanaman ekspor kepada petani di Jawa.

Pelaksanaan tanam paksa dalam kenyataannya tidak sesuai dengan peraturan yang berlaku pada masa itu. Sistem tanam paksa lebih menguntungkan pemerintah kolonial dan semata-mata sebagai bentuk eksploitasi (Booth, 1988: 101). Dalam pelaksanaan sistem tanam paksa, van den Bosch menghendaki peningkatan campur tangan orang Eropa dalam proses produksi. Rakyat dipaksa menanam tanaman ekspor yang diminta pemerintah di tanah-tanah milik mereka sendiri. Penyerahan hasil tanaman, menurut teorinya, dilakukan atas kemauan penduduk 
sendiri namun tentu dalam kenyataannya tidaklah demikian.

Tuntutan kerja paksa (kerja rodi) atau pekerjaan tanam paksa diwajibkan bagi penanaman kopi yang hampir semuanya dilakukan di tanah yang belum digarap, meskipun pada praktiknya penanaman juga dilakukan di lahan pertanian yang sudah digarap. Dalam teorinya sebagai upah atas penanaman tanaman yang diminta pemerintah maka penduduk dibebaskan dari kewajiban membayar pajak tanah. Pajak nantinya dipungut bukan dalam bentuk uang melainkan dalam bentuk in natura atau dengan memberikan tenaganya untuk bekerja. Hal ini dianggap lebih sesuai dengan sifat rumah tangga desa yang ingin dipertahankan sebagai rumah tangga produksi dan dicegah agar tidak menjalankan rumah tangga uang (Kartodirdjo dan Suryo, 1991: 55).

Aturan mengenai pelaksanaan sistem tanam paksa pada dasarnya masih dapat diterima karena masih berada dalam koridorkoridor kewajaran yang masuk akal. Permasalahannya ialah dalam praktiknya sistem tanam paksa menyimpang dari aturan yang ditetapkan. Menurut Kartodirdjo dan Suryo (1991:56) di dalam Lembaran Negara (Staatsblad) tahun 1834, nomor 22, sistem tanam paksa dijalankan dengan ketentuan sebagai berikut :

1) Melalui persetujuan, penduduk menyediakan sebagian tanahnya untuk penanaman tanaman perdagangan yang dapat dijual di pasaran Eropa.

2) Tanah yang disediakan untuk penanaman tanaman perdagangan tidak boleh melebihi seperlima dari tanah pertanian yang dimiliki penduduk desa.

3) Pekerjaan yang diperlukan untuk menanam tanaman perdagangan tidak boleh melebihi pekerjaan yang dibutuhkan untuk menanam padi.

4) Bagian tanah yang ditanami tanaman perdagangan dibebaskan dari pembayaran pajak tanah.

5) Hasil tanaman perdagangan yang berasal dari tanah yang disediakan wajib diserahkan kepada pemerintah Hindia Belanda; apabila nilai hasil tanaman perdagangan yang ditaksir itu melebihi pajak tanah yang harus dibayar rakyat, maka selisih positifnya harus diserahkan kepada rakyat.

6) Kegagalan panen tanaman perdagangan harus dibebankan kepada pemerintah, terutama apabila kegagalannya bukan disebabkan oleh kelalaian penduduk.

7) Penduduk desa akan mengerjakan tanah mereka dengan pengawasan kepalakepala mereka, dan pegawai-pegawai Eropa membatasi pengawasannya pada segi teknis dan ketepatan waktu dalam pembajakan tanah, panen, dan pengangkutan.

Sistem tanam paksa dilaksanakan melalui saluran birokrasi pemerintah, yang melibatkan pejabat-pejabat pribumi dan 
Eropa. Pejabat pribumi mencakup para bupati hingga kepala desa.Pejabat Eropa meliputi para Residen, Asisten Residen, Kontrolir, dan Direktur Tanaman, yang bertugas sebagai pengawas jalannya pelaksanaan system tanam paksa.Ini berarti sistem tanam paksa menyandarkan diri pada sistem tradisional dan feodal dengan perantaraan struktur kekuasaan lama (Kartodirdjo, 1993:306). Sistem liberal yang sempat dianut ditinggalkan sama sekali.

Meskipun dapat ditarik suatu konklusi secara umum bahwa sistem tanam paksa membawa penderitaan, akan tetapi sistem tanam paksa membawa dampak besar bagi perubahan sosial ekonomi petani Jawa. Subsistensi yang sejak dulu menjadi warna dalam perekonomian petani Jawa mengalami pergeseran. Secara perlahan namun pasti sistem tanam paksa telah memperkenalkan perekonomian uang yang kemudian semakin berkembang dengan masuknya modal asing dalam koridor ekonomi liberal.

Perubahan penting di bidang sosioekonomi di Jawa nampakya dimulai sejak diberlakukannya sistem tanam paksa pada tahun 1830 dan berakhir dengan munculya depresi ekonomi pada pertengahan 1880an. Sisi terpenting dari perubahan tersebut adalah makin melemahnya ciri subsisten kehidupan perekonomian pribumi. Gaya hidup lama rumah tangga petani pencari nafkah yang memproduksi sebagian besar kebutuhan materinya sendiri perlahan berpindah ke kehidupan materi yang lebih komersial. Penduduk desa semakin terbiasa membeli berbagai jenis kebutuhan rumah tangga. Dampak ekonomi dalam bentuk kebiasaan konsumen yang berubah dari penduduk desa dicerminkan oleh semakin banyaknya jumlah orang yang terlibat penuh dalam kegiatan ekonomi nonpertanian (Linblad, 1998: 131).

Secara umum pelaksanaan sistem tanam paksa telah mempengaruhi dua unsur pokok kehidupan agraris pedesaan Jawa, yaitu tanah dan tenaga kerja. Akan tetapi menurut Niel dalam Booth (1988 :130), dampak dari sistem tanam paksa di Jawa selain mempengaruhi tanah (kemudian dikaitkan dengan sistem ekonomi pedesaan) dan munculnya tenaga buruh yang murah, masih ditambah satu hal lagi yaitu lahirnya pembentukan modal di desa. Perolehan laba yang sangat luar biasa bagi Belanda menunjukkan bahwa sistem tanam paksa merupakan eksploitasi Belanda, terutama di Jawa pada periode 1830-1870.

Sistem tanam paksa pertama-tama mencampuri urusan kepemilikan tanah penduduk pedesaan, karena petani harus menyerahkan tanahnya untuk penanaman tanaman ekspor.Tuntutan akan kebutuhan tanah pertanian untuk tanaman ekspor yang dilakukan dengan menggunakan ikatan desa, telah mempengaruhi pergeseran pemilikan dan penguasaan tanah di kalangan petani pedesaan. Hal ini 
dikarenakan adanya pertukaran atau pembagian tanah pertanian untuk perataan pembagian kewajiban penyediaan tanah dan kerja pada pemerintah, maupun adanya kecenderungan perubahan kepemilikan tanah perseorangan menjadi tanah komunal desa.

Menurut Niel dalam Booth (1988:118) menjelaskan bahwa sistem tanam paksa telah menghancurkan desa-desa di Jawa, karena telah memaksa mengubah hak kepemilikan tanah desa menjadi milik bersama dan dengan demikian merusak hakhak perorangan yang lebih dulu atas tanah. Hal ini menurut Clifford Geertz dalam teori involusi pertaniannya, mengakibatkan munculnya homogenisasi sosial di desadesa Jawa yang mengakibatkan kemiskinan bersama (shared poverty).Hal inilah yang kemudian melahirkan sistem ekonomi pedesaan yang terus berlanjut meskipun sistem tanam paksa mulai memudar.

Selain tanah, sistem tanam paksa membutuhkan pengerahan tenaga kerja rakyat secara besar-besaran untuk penggarapan lahan, penanaman, pemanenan, pengangkutan, dan pengolahan di pusat-pusat pengolahan atau pabrik. Semua kerja yang dibutuhkan ini dilakukan dengan sistem kerja paksa. Pelaksanaan heerendiensten sangat memberatkan penduduk, karena selain tidak diberi upah, juga pekerjaan yang harus dikerjakan secara fisik cukup berat. Meskipun nantinya secara berangsur-angsur sistem kerja paksa di perkebunan diganti menjadi sistem kerja upah bebas. Sejak tahun 1837 mulai dilakukan individualisasi pekerjaan dalam perkebunan. Tahun 1855 sistem pekerjaan di perkebunan mulai teratur dan terspesifikasi. Pekerjaan di perkebunan maupun di sektor pembangunan mulai memberlakukan sistem kontrak (Kartodirdjo dan Suryo, 1991 : 67-68).

Meskipun pemerintah kolonila menjalankan politik "tidak campur tangan" semakin intensifnya ekonomi Belanda di Jawa telah menyebabkan makin hilangnya kehidupan tradisional masyarakat Jawa. Ketika kaum bangsawan Jawa gagal dalam ushanya untuk melebarkan kepemimpinan mereka dalam bidang ekonomi, mengundurkan diri kembali ke dalam tradisi Jawa dengan pengecualian beberapa orang mendapat pendidikan Barat dalam mencarijalan keluar bagi bakat dan ambisi mereka di bidang politik (Geertz, 1983: 14).

Menurut Geertz (1983: 55) sistem tanam paksa mempunyai arti yang sangat menentukan dalam pemusatan hampir seluruh usaha di Jawa. Sistem itu telah memberikan bentuk terakhir pada perbedaan yang ekstrim antara Jawa dengan luar Jawa dan semenjak ituperbedaan semakin besar. Sistem itu memantapkan dan menonjolkan pola ekonomi rangkap dengan sektor Barat yang padat modal dan sektor Timur yang padat karya, karena sistem itu menyebabkan makin pesatnya perkembangan sektor Barat dan 
mempercepat membekunya sektor Timur, dan jurang ini makin melebar dan mendalam dengan penanaman modal Belanda. Lebih penting lagi sistem itu telah mencegah pengaruh akibat makin mendalamnya penetrasi Barat kedalam kehidupan petani dan priyayi Jawa, sehingga modernisasi pertanian di kalangan pribumi pada saat yang sangat menguntungkan tidak terjadi proses itu.

Pelaksanaan sistem tanam paksa telah mempengaruhi dua unsur pokok kehidupan agraris pedesaan Jawa, yaitu tanah dan tenaga kerja. Sistem tanam paksa pertamatama mencampuri sistem pemilikan tanah penduduk pedesaan, karena para petani diharuskan menyerahkan tanahnya untuk penanaman tanaman ekspor. Tuntutan akan kebutuhan tanah pertanian untuk penanaman tanaman ekspor yang dilakukan dengan menggunkan ikatan desa, telah mempengaruhi pergeseran pemilikan dan penguasaan tanah di kalangan petani pedesaan.

Pergeseran sistem pemilikan dan penguasaan tanah ini terjadi karena berbagai sebab, baik karena adanya pertukaran atau pembagian tanah-tanah pertanian untuk perataan pembagian kewajiban penyediaan tanah dan kerja kepada pemerintah, maupun karena adanya kecenderungan perubahan pemilikan tanah perseorangan menjadi tanah komunal desa.

Pertukaran tanah garapan terjadi terutama di daerah pusat penanaman dan pabrik tebu. Petani-petani di daerah sekitar pabrik gula yang tanah sawahnya harus ditanami tebu, mendapat pengganti tanah garapannya di daerah pedesaan yang ada di luar lingkaran penanaman dan pengolahan tebu. Pertukaran dan pergeseran semacam itu dilakukan oleh penduduk sendiriatau diatur oleh pemerintah setempat. Cara ini banyak menimbulkan kesulitan penduduk, karena tidak jarang penduduk menerima pengganti lahan garapannya terletak jauh dari tempatkediamanya, sehingga banyak waktu dan tenaga yang harus disediakan untuk mengerjakan lahan mereka (Kartodirjo dan Suryo, 1991: 66).

Dirk van Hongedorp dalam (Burger, 1957: 146) berpendapat bahwa stelsel feodal yag terdapat di Indonesia mematikan segala kemauan berusaha. Menurutnya stelsel ini lebih dari pada iklim, adalah penyebab dari penyakit masa bodoh orangorang Jawa. Karena itu ia ingin mencabut kekuasaan dan hak mengguasai atas tanah dari para bupati dan memberikan hak memiliki tanah kepada para petani, yakni dijamin kepastian tentang milik tanahnya. Kemudian menghendaki kebebasan menanam dan mempergunakan hasil tanamannya, mengubah penyerahan paksa menjadi penjualan bebas dan ekspor yang bebas dari hasil yang ditanamnya sendiri.

Rakyat akan dipaksa menanam tanaman-tanaman ekspor pada tanah-tanah mereka sendiri. Sebelum itu hanya dituntut penyerahan bahan-bahan yang dihasilkan 
atas kemauan mereka sendiri, sedangkan rodi serta pekerjaan tanam paksa hanya diwajibkan bagi penanaman kopi. Penanaman kopi yang diwajibkan itu hampir seluruhnya dilakukan diatas tanahtanah liar. Apabila dipergunakan juga tanahtanah pertanian maka hal itu berarti bahwa pergaulan hidup desa akan dicampuri lebih mendalam.

Sebagai upah atas penanaman itu tidaklah diberikan uang, tetapi diberikan pembebasan dari kewajiban membayar pajak tanah yang sangat berat itu, dengan demikian maka pajak itu tidak dipungut dalam uang melainkan dalam natura (kerja). Pajak ini lebih sesuai dengan sifat rumah tangga desa daripada pajak dalam uang yang menyebabkan rakyat terpaksa menjual barang-barang hasilnya sehingga mudah disesatkan atau tertipu (Burger, 1957: 198).

Perluasan penanaman padi di sawah dan pembayaran gaji yang disediakan oleh pemerintah kolonial dan pabrik-pabrik gula swasta sepenuhnya merupakan akibat rangsangan perusahaan bebas (free enterprise) di Jawa setelah 1813. Pengolahan sawah pada dataran rendah dan penanaman kopi di dataran tinggi mendorong kehidupan menetap (sedentary life). Penenman tanaman sekunder disamping padi menunjukkan bahwa sedikit banyak komersialisasi juga sedag terjadi. Komersialisasi juga didorong oleh pertumbuhan kegiatan perdagangan yang pada mulanya berpusat pada pelabuhanpelabuhan di Indramayu dan Cirebon.

Daerah-daerah yang dikendalikan oleh Belanda, terdapat dua sistem tenaga kerja yang beroperasi secara pararel. Pertama, tenaga kerja paksa yang direkrut dari para petani desa dan dipekerjakan oleh pejabat-pejabat supradesa untuk pelayanan masyarakat. Pada dasarnya, hal ini merupakan sejenis pajak yang ditarik dari para petani pemilik tanah. Sistem kedua adalah tenaga kerja bayaran yaitu petani bekerja pada tanahnya sendiri dan bekerja untuk orang lain dan menerima bayaran.

Berdasarkan jenis kerja dan perkembangan ekonomi daerah, terdapat berbagai jenis pembayara, mulai dari hasilhasil pertanian kemusian tanah sampai uang. Tampaknya menyesatkan jika kita beranggapan bahwa system kerja paksa mendominasi masyarakat desa sedemikian rupa sehingga petani hampir tidak mempunyai kebebasn untuk bekerja bagi dirinya sendiri. Dalam kenyataannya para petani sebelum abad ke-19 menikmati relatif lebih banyak kebebasan bekerja bagi dirinya sendiri daripada saat mereka beada di bawah system tanam paksa (Linblad, 1998: 217).

Kerja paksa di kesultanan Jawa mempunyai beberapa karakteristik yang khas. Pertama, fungsi utama kerja paksa adalahmemberikan pelayanan pribadi pada kelas atas atau supradesa. Karena itu, tingkat kerja paksa berbeda dari satu 
daerah ke daerah yang lain. Bebrapa pejabat menuntut banyak pelayanan, sedangkan yang lain tidak. Kedua, kerja paksa untuk kepentingan umum dan infrastruktur digunakan dalam skala kecil dan untuk jenis kerja yang sederhana. Ketiga, secara umum, tidak banyak tenaga kerja direkrut dari tempat-tempat jauh di luar daerah atau desa. Keempat, mobilisasi kerja skala besar (gugur gunung)hanya diperlukan untuk menangani bencana-bencana atau untuk tujuan upacara-upacara besar di ibu kota. Kelima, para petani yang terkena wajib militer direkrut dari tiap pemilik tanah kapan saja Sultan pergi berperang, namun tugas ini jarang dilaksanakan setelah perjajian Giyanti 1755.

Sistem tanam paksa selama empat dasawarsa telah berhasil menutupi defisit yang diderita pemerintah Belanda, bahkan dapat meningkatkan kemakmuran bangsa Belanda sendiri. Jumlah total dari batig slot atau keuntungan yang diperoleh Belanda dari hasil tanam paksa mencapai angka $f$ 784 juta sesuatu angka yang tinggi pada masa itu (Djoenoed, 1993: 95). Sementara dipihak lain, beban yang dipikul rakyat bertambah berat. Penderitaan rakyat tersebut disebabkan oleh kerja rodi yang mereka lakukan baik untuk membangun dan memelihara benteng-benteng tentara kolonial maupun juga perawatan infrastruktur berupa jalan, jembatan dan irigasi. Banyak dari pekerja rodi tersebut kemudian mati karena penyakit dan kekurangan makanan yang disebabkan perawatan kesehatan yang kurang bagus.

Pada tahun 1840, tanda-tanda penderitaan di kalangan masyarakat Jawa mulai tampak, khususnya di daerah-daerah penanaman tebu. Batang tebu ditanam ditanah yang sama untuk penanaman padi. Waktu yang diperlukan untuk tumbuhnya tebu dan menuainya disusul dengan persiapan lahan bagi penanaman padi telah mempersulit tercapainya pergiliran yang konstant bagi kedua komoditi tersebut. Pabrik-pabrik gula juga bersaing dengan pertanian padi untuk jatah air. Nila juga menciptakan masalah, gizi tanah menjadi terkuras sehingga mengakkibatkan tanaman padi buruk beberapa tahun setelah lahan ditanami nila sehingga terjadi kekurangan beras. Harganya menjadi bergejolak dimana-mana yang paling kuat terjadi pada tahun 1830-an dan 1840-an.

Kelaparan-kelaparan yang melanda Jawa lebih disebabkan oleh kemelaratan petani dan keserakahan orang-orang yang memegang kekuasaan ketimbang oleh kelangkaan beras. Pada tahun 1844 terjadi gagal panen besar-besaran yang diikuti oleh kelaparan di Cirebon. Wabah-wabah penyakit khususnya tipus berjangkit pada tahun 1846-1850. Sementara itu pemerintah menerapkan kenaikan pajak tanah dan pajak-pajak lainnya secara drastis. Kepergian penduduk dari desa-desa mengakibatkan semakin turunnya hasil pertanian padi (Ricklefs, 2001: 267). Sistem 
Tanam Paksa telah menyebabkan penilaian yang negatif bagi pekerjaan karena memberikan kompensasi atau ganti rugi serendah mungkin. Dengan meneruskan penggunaan pola-pola kekuasaan tradisional. Sistem Tanam Paksa juga merubah sistem kerja mayarakat yang telah mengenal sistem ekonomi uang (monetisasi) ke dalam lingkungan kehidupan pedesaan agraris (Kartodirdjo dan Suryo, 1991:68).

Kehidupan perekonomian yang semula masih tradisional dan subsisten secara berangsur-angsur berkenalan dengan ekonomi uang melalui komersialisasi produksi pertanian dan pasaran kerja. Sistem tanam paksa telah menjadi pintu masuk peredaran uang ke daerah pedesaan. Sistemekonomi uang ini membuat para petani mulai tergantung pada dunia luar. Produksipertanian dirasakan sebagai komoditi untuk ekspor dan pasar dunia. Sistem ini mulai menggoyang sistem ekonomi subsisten sebagai ekonomi tradisional yang bersifat tertutup dan memenuhi kebutuhan rumah tangga sendiri bagi petani.

Salah satu dampak dari cultuurstelsel adalah masuknya ekonomi uang di pedesaan. Penduduk membayar pajak tanah (landrent) yang diintroduksi oleh Raffles dengan uang. Kenyataan ini saja sudah menunjuk adalah perubahan dalam kehidupan pedesaan. Suatu masalah yang penting pula adalah apa yang dinamakan "cultuur procent" (Fasseur, 1986), yaitu jumlah persentase yang diterima para pejabat Belanda maupun sesuai dengan produksi yang diserahkan pada gudanggudang pemerintah. Jumlah itu tidak jarang jauh lebih besar dari gaji yang diterima. Van den Bosch sengaja menambah hal ini untuk mendorong para pejabat tersebut bekerja keras. Lagi pula cara itu juga sudah dipakai dalam Preangerstelsel, dengan demikian cara ini sesungguhnya bukan ciptaan van den Bosch.

Banyaknya eksploitasi tenaga kerja serta tanah pertanian menyebabkan penderitaan rakyat yang semakin berat. Bagi para petani yang menjadi buruh upahan di pabrik-pabrik secara umum ekonomi mereka relatif baik. Namun para petani tidak mempunyai kesempatan mengerjakan tanahnya atau tanahnya dijadikan perkebunan pemerintah maka penderitaanlah yang terjadi, sehingga muncullah reaksi dari masyarakat Jawa.

Salah satu reaksi tersebut adalah dengan cara berpindah jauh dari desanya untuk menghindari beban-beban atau untuk mencari pekerjaan. Upaya penghindaran diri digambarkan oleh masyarakat Jepara yang ramai-ramai melarikan diri, menyingkir dan migrasi lemah di Jawa bila tekanan tuntutan pihak yang berkuasa telah terlampau berat menimpa diri mereka. Sejak tahun-tahun pertama pelaksanaan tanam paksa sudah terjadi penyingkiran diri dari beberapa ribu petani dari Jepara. Hal ini menyulitkan pemerintah karena 
kehilangan tenaga kerja yang begitu diperlukan bagi perkebunan tanam paksa. Pada tahun 1841 kesulitan itu timbul kembali dengan perpindahan penduduk dalam jumlah besar, pada enam bulan pertama tahun itu sudah sekitar 2.000 petani menyingkir ke daerah sebelah selatan Grobogan, daerah yang tidak terlibat tanam paksa dan juga tanpa adanya kerja rodi (Husken, 1998: 112).

Bentuk-bentuk perlawanan lain terlihat juga seperti sabotase, tindakantindakan kekerasan perseorangan dan demonstrasi protes secara bersama. Biasanya ini terjadi di daerah-daerah yang memiliki tanggung jawab besar untuk menghasilkan komoditi-komoditi pertanian untuk pemerintah maupun di daerah yang memiliki tanggung jawab sedikit atau yang tidak memiliki sama sekali. Ini menunjukkan bahwa banyak persoalan yang dirasakan masyarakat Jawa karena kondisi umum pemerintah Belanda dari padapengaturan-pengaturan khusus dalam tanam paksa (Ricklefs, 2001: 226).

Pergolakan di daerah pedesaan sebagai bentuk perlawanan terhadap kekuasaan asing ternyata bersifat endemis, local, pendek umurnya serta tradisional. Gerakan yang tradisional ini tidak mampu meluaskan jaringan organisasinya, basis komunitasnya tetap unit social tradisional yang merupakan komunitas desa, keluarga dan lembaga tradisional religius. Menurut Suhartono (1991: 140-165) terdapat tiga kategori gerakan sosial sebagai bentuk perlawanan terhadap kekuasaan Belanda dan elit local. Pertama, gerakan dan ideologimesianisme yang mengandung harapan datangnya zaman adil dan makmur. Gerakan ratu adil merupakan kontraideologi terhadapraja sebagai penguasa yang tentu akan mengancam kedudukan penguasa. Kedua adalah gerakan bercorak nativisme. Gerakan ini tidak dapat dipisahkan dari besarnya kekuasaan asing sehingga menciptakan reaksi kuat untuk melenyapkannya.

Meluasnya kekuasaan asing berarti merosotnya ketertiban di berbagai bidang kehidupan, sehingga pengusiran orang asing termasuk sekutunya menjadi tujuan utama gerakan itu karena membentuk kelompok penguasa. Ketiga adalah gerakan protes perorangan yang terdapat di pedesaan. Munculnya gerakan ini merupakan pelampiasan frustasi karena tekanantekanan dari perusahaan perkebunan. Berdasarkan ideologi yang dianutnya disertai keberanian dan kekebalan mendorong pemimpin gerakan melakukan protes terhadap perusahaan perkebunan. Selain gerakan perorangan yang bersifat terorganisir, terdapat bentuk pelawanan yang dilakukan secara perseorangan yang terjadi di pedesaan antara lain perkecuan, pembegalan, pembakaran, pencurian ternak dan pembunuhan. Umumnya para kecu atau bandit terorganisir dengan baik dan 
mempunyai markas serta pimpinan yang disebut benggol kecu.

Pada akhirnya, sistem ekonomi modern yang muncul akibat tanam paksa meskipun berhasil mendorong Jawa makin terlibat dalam perdagangan internasional karenapertumbuhan yang mantap di bidang ekspor, namun di sisi lain telah mengeksploitasi habis-habisan sistem ekonomi subsistens yang menjadi basis ekonomi kaum tani.

Eksploitasi lewat sistem tanam paksa bersifat brutal dan mengakibatkan petani Jawa menderita kemiskinan dan kelaparan. Struktur sosial dan ekonomi Jawa nyaris dihancurkan. Kemiskinan dan kelaparanmenjadi masalah pokok penduduk Jawa. Teori involusi pertanian Clifford Geertz yang menjelaskan proses kemiskinan structural di Jawa tampak relevansinya. Pertambahan penduduk Jawa, berkurangnya lahan pertanian dan perluasan perkebunan Eropa menjadi penyebab kemiskinan di Jawa.

\section{PENUTUP}

Sistem tanam paksa lebih mengutamakan peningkatan hasil produksi tanaman ekspor yang sangat laku di pasaran Eropa. Pemerintah kolonial memperkenalkan tanaman ekspor kepada petani di Jawa. Pelaksanaan tanam paksa dalam kenyataannya tidak sesuai dengan peraturan yang berlaku pada masa itu. Sistem tanam paksa lebih menguntungkan pemerintah kolonial dan semata-mata sebagai bentuk eksploitasi. Rakyat dipaksa menanam tanaman-tanaman ekspor pada tanah-tanah mereka sendiri. Sebelum peristiwa tanam paksa terjadi, fenomena yang ada yakni rakyat hanya dituntut menyerahkan bahan-bahan yang dihasilkan atas kemauan mereka sendiri. Tanaman yang wajib ditanam yaitu kopi. Penanaman kopi yang diwajibkan itu hampir seluruhnya dilakukan diatas tanah-tanah liar. Apabila dipergunakan juga tanah-tanah pertanian maka hal itu berarti bahwa pergaulan hidup desa akan dicampuri lebih dalam.

Perubahan di bidang sosio-ekonomi di Jawa dimulai sejak diberlakukannya sistem tanam paksa pada tahun 1830 dan berakhir dengan munculya depresi ekonomi pada pertengahan 1880 -an. Sisi terpenting dari perubahan tersebut adalah makin melemahnya ciri subsisten kehidupan perekonomian pribumi. Gaya hidup rumah tangga petani pencari nafkah yang mulanya memproduksi sebagian besar kebutuhan materinya sendiri perlahan berpindah ke kehidupan materi yang lebih komersial. Kehidupan perekonomian yang semula masih tradisional dan subsisten secara berangsur-angsur berkenalan dengan ekonomi uang melalui komersialisasi produksi pertanian dan pasaran kerja. Sistem Tanam Paksa telah menyebabkan penilaian yang negatif karena memberikan kompensasi atau ganti rugi yang sangat rendah. 


\section{DAFTAR PUSTAKA}

Booth, Anne et.al. 1988. Sejarah Ekonomis Indonesia. Jakarta: LP3ES.

Burger, D.H. 1957. Sedjarah Ekonomis Sosiologis Indonesia 1. Jakarta: Pradjna Paramita.

Djonoed, Marwati dkk. 1993. Sejarah Nasional Indonesia $V$. Jakarta: Balai Pustaka.

Fasseur, C. De Indologen. 1993. Ambtenaren voor de oost 1825-1950. Amsterdam.

Geertz, Clifford. 1983. Involusi Pertanian. Jakarta: Bharata.

Husken, Frans. 1998. Masyarakat Desa dalam Perubahan Zaman. Jakarta: Gramedia Widiasarana Indonesia.

Kartodirdjo, Sartono dan Suryo, Djoko. 1991. Sejarah Perkebunan di Indonesia Kajian Sosial Ekonomi. Yogyakarta: Aditya Media.

Kartodirdjo, Sartono . 1993. Pengantar Sejarah Indonesia Baru: 1500-1900 Dari Emporium Sampai Imperium Jilid 1. Jakarta:Penerbit PT Gramedia Pustaka Utama.

Lindblad, Thomas J. 1998. Sejarah Ekonomi Modern Indonesia: Berbagai Tantangan Baru. Jakarta: LP3ES.

Ricklefs, M.C. 1991. Sejarah Indonesia Modern. Yogyakarta: Gadjah Mada University Press.

Suhartono. 1991. Apanage dan Bekel: Perubahan Sosial di Pedesaan Surakarta (1830-1920). Yogyakarta: Tiara Wacana. 